\title{
Additions to the Plants of Saskatchewan
}

\section{August J. Breitung}

A "List of the Flowering Plants, Ferns and Fern Allies of Saskatchewan" was published by W. P. Fraser and R. C. Russell in 1937, cataloguing 1,405 plant species, based on herbarium specimens preserved in the University of Saskatchewan, Saskatoon. The list aroused further interest in the flora of Saskatchewan, and as a consequence many species not previously recorded were collected. In 1944, "A Revised Annotated List of the Plants of Saskatchewan" was published, listing 1,536 species which included 131 additions. Unfortunately, Dr.' Fraser died in 1943 before the second list was completed. The latter was, however, published after his death.

Following publication of the revised list (1944), the writer endeavored to maintain, as far as possible, a record of all the plants reported which have not previously appeared in the botanical literature available for Saskatchewan. No additions have been made without a study of the specimens cited below.

The nomenclature followed in the present list of 42 additions, is in accordance with that used in Fraser and Russell's List-the purpose being to make both lists more convenient to use coricurrently.

Botrychium simplex E. Hitchc. Little Grape-fern. Cypress Hills.

Lila ea scillioides (Poir.) Haum. Flowering Quillwort. Trossachs.

Alopecurus occidentalis. Scribn. Western Foxtail. Cypress Hills.

Panicum Wilcoxianum Vasey Wilcox's Panic-grass. Prince Albert.

Poa nevadensis Vasey Nevada Bluegrass. Cypress Hills.

Carex microptera Mack. Smallwinged Sedge. Cypress Hills.

Scirpus Clintoni A. Gray Clinton's Rush. Meadow Lake.

Luzula parviflora (Ehrh.) Desv. Small-flowered Wood-rush. Candle Lake, Meadow Lake, Ille a la Crosse, Lac la Ronge.

Rumex obtusifolius L. Blunt-leaved Dock. Roadside ditch. Weyburn Introduced).

R. orbiculatus A. Gray Water Dock. Sulphide Lake, Meadow Lake, Ille a la Crosse, Lac la Ronge.

Atriplex glabriuscula Edm. Smoothish Atriplex. Tuxford (Introduced).

Corispermum hyssopifolium L. Hyssop-leaved Bugseed. Introduced weed along railway track, Nipawin.

Arenaria propinqua Rich. Boreal Sandwort. Cypress Hills.

Silene Cserei Baumg. Cserei's Campion. Cypress Hills. (Introduced).

Thalictrum sparciflorum Turcz. Fewflowered Meadow-rue. Waskesiu Lake, Meadow Lake.

Caltha natans Pall. Water Marigold. Windrum Lake, north of the Churchill River.

Rhaphanus Rhaphanistrum L. Wild Radish. Tisdale. Weed in flax field associated with a serious infestation of Indian Mustard (Brassica juncea).

Crataegus Douglasii Lindl. Black Hawthorn. Cypress Hills.

Potentilla Blaschkeana Turcz. ( $P$. ctenophora Rydb.). Blaschke's Cinquefoil. Regina.

P. recta L. Upright Cinquefoil. Swift Current, Mortlach. (Introduced).

Prunus americana Marsh. American Wild Plum. Roch Percee.

Tithymalopsis lucidus (Waldst. \& Kit.) Kl. \& Garcke (Euphorbia lucida Waldst. \& Kit.). Shining Spurge. Kamsack. (Introduced).

Aralia hispida Vent. Bristly Sarsaparilla. Sulphide Lake, Windrum Lake.

ogswellia orientalis (Coult. \& Rose) M. E. Jones White-flowered Parseley. Bienfait.

Conium maculatum L. Poison Hemlock. Maclean.

Leptotaenia multifida Nutt. Cutleaved Wild Parsnip. Cypress Hills.

Osmorrhiza divaricata Nutt. Spreading Sweet Cicily. Cypress Hills.

Oxycoccus microcarpus Turcz. Small Cranberry. Candle Lake, Ile a la Crosse.

Chondrophylla Fremontii (Torr.) A. Nels. (Gentiana Fremontii Torr.). Fremont's Gentian. Mortlach.

Salvia lanceolata Willd. Lance-leaved Sage. Moosomin.

Besseya wyomingensis (A. Nels.) Rydb. Kitten-tails. Cypress Hills.

Mimulus Geyeri Torr. Geyer's Monkey-flower. Whitewood.

Scrophularia lanceolata Pursh Lanceleaved Figwort. Mortlach. 
Lobelia Dortmanna L. Water Lobelia. Windrum Lake.

Antennaria anaphaloides Rydb. Pussy-paws. Cypress Hills.

A. corymbosa E. Nels. Pussy-paws. Cypress Hills. New to the flora of Canada.

A. imbricata E. Nels. Pussy-paws. Cypress Hills.

Artemisia vulgaris L. Common Mugwort. Hoosier. (Introduced).

Gnaphalium uliginosum L. Low Cudweed. Loon Lake.

Liatris aspera (Michx.) Greene Large Button-snakeroot. Gainsborough, Antler.

\section{APPENDIX}

The following 8 species were reported from Saskatchewan in Fraser and Russell's List (1944), but inadvertently cited as other entities:

Picea albertiana S. Brown Alberta White Spruce. Cypress Hills. (See fig. 1). Reported as P. glauca.

Juncus saximontanus A. Nels. Rocky Mountain Rush. Cypress Hills. Reported as $J$. Mertensianus.

Smilacina amplexicaulis Nutt. Western Solomon's Seal. Cypress Hills. Reported as $S$. racemosa.

Listera borealis Morong Northern Twayblade. Cypress Hills. Reported as $L$. convallarioides.

Arenaria stricta (Sw.) Michx. Upright Sandwort. McKague. Reported as $A$. verna.

Crataegus columbiana Howell Columbia Hawthorn. Cypress Hills. Reported as C. succulenta.

Aster modestus Lindl. Modest Aster. Reported as A. Franklinianus. Macdowall, Meadow Lake, Ile a la Crosse, Loon Lake.

Hieracium columbianum Rydb. Columbia Hawksbeard. Cypress Hills. Reported as H. cynoglossoides.

\section{Yellow Chokecherries \\ By Lad. Martinovsky, Gerald}

The article on yellow chokecherries took $m y$ attention in the last BLUE JAY. I have been growing yellow chokecherries in my fruit garden for about eighteen years. We got the first plants from a nursery in Manitoba, but shortly after we found some growing wild about sixteen miles south of here.

A neighbor of mine found white Saskatoons growing in the Qu'Appelle Valley a number of years back. I intended to go and dig up a few plants but I have not done so yet.

\section{Almost a Complete Set} H. H. Bridgewater, Bredenbury, Sask.

W HILE browsing through my stacks of BLUE JAYS today, I was delighted to find that I have the complete issue with the exception of Volume 1, No. 1. Regarding the first magazine, I would not ask anyone for it. If there are any around they will likely be highly valued. However, I would be glad to pay for a printed copy of this if anyone knows how it could be obtained.

The early editorials and pieces by the late Mrs. I. M. Priestly are wonderful. Her breezy outdoorish pen was both exciting and restful and the lively zest with which she wrote, and must have lived, would have carried both herself and the BLUE JAY far had she lived. I think a copy of editorials and writings by this great naturalist would make a splendid special issue for the BLUE JAY some year.

I believe the day should not be too far away when your splendid magazine is found in newsstands throughout the country and subscribed to by schools in Western Canada.

\section{A Worthy Incentive}

New subscribers to the BLUE JAY from the city of Yorkton will automatically receive one year's free membership in the Yorkton Natural History Society. This ruling is a result of a motion passed at the regular meeting of that Society on January 10 last. This will provide an incentive for those interested in nature to become acquainted with both societies for only one dollar the first year, instead of asking for $\$ 1.50$ "right off the bat."

This move is a very worthy and unselfish one on the part of the Yorkton Society. The Editor of the BLUE JAY, on behalf of the Saskatchlewan Natural History Society, offers their sincere thanks for this gesture of confidence and co-operation. 